\title{
Inhibition of cyst formation in the toxic dinoflagellate Alexandrium (Dinophyceae) by bacteria from Hiroshima Bay, Japan
}

\author{
Masao Adachi ${ }^{1, *}$, Tomoyuki Matsubara ${ }^{1}$, Ryo Okamoto ${ }^{1}$, Toshitaka Nishijima ${ }^{1}$, \\ Shigeru Itakura ${ }^{2}$, Mineo Yamaguchi ${ }^{2}$
}

\author{
${ }^{1}$ Laboratory of Aquatic Environmental Science, Faculty of Agriculture, Kochi University, Kochi 783-8502, Japan \\ ${ }^{2}$ Harmful Phytoplankton Section, Harmful Algal Bloom Division, National Research Institute of Fisheries and Environment \\ of Inland Sea, Fisheries Research Agency, Ohno, Saeki, Hiroshima 739-0452, Japan
}

\begin{abstract}
The relationship between the abundance of the toxic marine dinoflagellate Alexandrium tamarense (Lebour) Balech and cyst formation-inhibiting bacteria (Alex-CFIB) was investigated in samples taken from the water column in Hiroshima Bay (Japan) in 1999. The cell density of A. tamarense peaked in the middle of April and blooms declined in May. Alex-CFIB were detected during the bloom period as well as the non-bloom period in 1999 by means of the most probable number (MPN) bioassay as well as the colony counting method. A total of 32 strains that had potential Alexandrium cyst formation-inhibiting activities (CFIB) were isolated from the seawater samples from Hiroshima Bay throughout the year. The population structure and genetic diversity of AlexCFIB were analyzed by means of restriction fragment length polymorphism (RFLP) of the 16S ribosomal RNA genes (16S rDNA). Five ribotypes, Ia to Id and II types, were determined among the 32 strains of Alex-CFIB. Most of the strains belonged to ribotype I, suggesting that bacteria of ribotype I may be dominant in the Alex-CFIB assemblages in the field seawater. Almost the entire 16S rDNAbased phylogenetic tree showed that ribotypes I and II fell into the class Proteobacteria $\gamma$-subdivision Alteromonas group and the Vibrio group, respectively. The 6-well microplate approach clarified that Alex-CFIB obtained in this study do not have growth-inhibiting activities, and Alex-CFIB of ribotype I (Alteromonas group) have strong activities of encystment inhibition among these ribotypes. The existence not only of Alexandrium cyst formation-promoting bacteria (Alex-CFPB) reported previously but also of Alex-CFIB in Hiroshima Bay throughout the year suggests that Alex-CFPB, as well as Alex-CFIB, especially bacteria of ribotype I, may play significant roles in the process of encystment and bloom dynamics of Alexandrium in the natural environment.
\end{abstract}

KEY WORDS: Alexandrium $\cdot$ Dinoflagellate $\cdot$ Bacteria $\cdot$ Cyst

Resale or republication not permitted without written consent of the publisher

\section{INTRODUCTION}

Alexandrium catenella and A. tamarense marine dinoflagellates produce potent neurotoxins such as gonyautoxins and saxitoxin and are responsible for paralytic shellfish poisoning (PSP) (Hallegraeff 1993, Shumway 1993).

The life cycle mode of these toxic species is extremely important for their ability to form blooms. It

*E-mail: madachi@cc.kochi-u.ac.jp is known that asexual reproduction by division can be replaced by the sexual fusion of the motile mating plus and minus cell types, yielding a motile diploid zygote (planozygote) (Turpin et al. 1978, Yoshimatsu 1981). The planozygote swims for several days and then becomes the non-motile resting cyst (hypnozygote) (Pfiester \& Anderson 1987). When favorable growth conditions return, cysts germinate and re-inoculate the water with asexual (vegetative) swimming cells that can act as potential seed populations, which can initiate red tide events (Steidinger 1975, Dale 1977, Anderson \& Wall 1978, Pfiester \& Anderson 1987). 
It is important to elucidate the environmental factors that affect cyst formation in these toxic dinoflagellates in considering the production of cysts in their natural habitats. In laboratory cultures, sexuality of dinoflagellates has been reported to occur in response to stress following nitrogen and/or phosphorus depletion (Pfiester \& Anderson 1987). There are, however, field reports of encystment under seemingly favorable nutrient conditions for growth. Anderson \& Morel (1979), Anderson et al. (1983) and Perez et al. (1998) reported cyst formation for natural populations of Alexandrium tamarense in the presence of relatively high levels of nitrate and phosphate capable of supporting vegetative growth.

Recently, we have focused on one of the possible biological factors, bacteria, that interact with toxic dinoflagellate Alexandrium. We clarified the existence of Alexandrium cyst formation-promoting bacteria (Alex-CFPB) in the field by bioassay using natural seawater samples from Hiroshima Bay (Adachi et al. 1999). The clear positive correlation between the abundance of $A$. tamarense and Alex-CFPB during the bloom periods suggested that the Alex-CFPB may play a significant role in the process of encystment and bloom disintegration in the field (Adachi et al. 1999). In the present study, we undertook an investigation of the existence of Alexandrium cyst formation-inhibiting bacteria (Alex-CFIB) in Hiroshima Bay in 1999. Relationships between the abundance of Alex-CFIB and Alex-CFPB were also examined during this period. We also isolated Alex-CFIB from the field seawater samples and examined the structure of the Alex-CFIB assemblages by sequence comparison of their $16 \mathrm{~S}$ ribosomal RNA gene (rDNA) regions.

\section{MATERIALS AND METHODS}

Organisms and culture methods. All the experiments were conducted with clonal and axenic isolate 6ax (mating type plus) and TNY7 (mating type minus) Alexandrium catenella were originally established by R. Kondo in 1995 from Uchiumi, Tokushima, Japan, and by Y. Sako in 1987 from Tanabe Bay, Wakayama, Japan, respectively (Adachi et al. 1999). A. catenella TB93 (mating type plus), which was established by N. Nishibori in 1993 from Tachibana Bay, Tokushima, Japan, was also used. These cultures were grown in f/2 medium based on natural seawater without adding silicate (f/2-Si) using $10^{-5} \mathrm{M}$ Fe-EDTA as an iron source and chelator (Guillard \& Ryther 1962, Anderson et al. 1984). Cultures were grown at $20^{\circ} \mathrm{C}$ with a $14 \mathrm{~h}$ light:10 h dark cycle at $80 \mu \mathrm{mol}$ photons $\mathrm{m}^{-2} \mathrm{~s}^{-1}$. Sterility of each culture was periodically determined by the method described by Adachi et al. (1999).
Field measurements and sampling. Sampling was conducted from January to December in 1999 once a month during non-bloom periods or once a week during bloom periods at Stn 11 (Adachi et al. 1999), a shallow coastal site in Hiroshima Bay, western Seto Inland Sea, Japan. Water samples for Alexandrium tamarense cell counts were taken from depths of 0,2 , 5, 10 and $20 \mathrm{~m}$, and from $1 \mathrm{~m}$ above the bottom at Stn 11 (depth ca $22 \mathrm{~m}$ ), and their water temperature and salinity were measured by the method described by Adachi et al. (1999). The number of vegetative cells of A. tamarense in $1 \mathrm{ml}$ of each sample concentrated from 500 to $10 \mathrm{ml}$ was counted under a light microscope on the day of sampling. One liter of subsamples collected from the $5 \mathrm{~m}$ depth layer at Stn 11 was poured into acid-washed, autoclaved glass bottles and kept at $4^{\circ} \mathrm{C}$ in the dark during transit to the laboratory for analysis of any bacterial effect on encystment. The total bacterial number in the seawater sample fixed with formaldehyde (final conc. $2 \%$ ) was determined by direct microscopic observations with 4',6-diamidino-2phenylindole (DAPI) staining (Porter \& Feig 1980).

Most probable number bioassay of Alex-CFIB and Alex-CFPB. The most probable number (MPN) bioassay (Adachi et al. 1999) was used for the detection and tentative enumeration of bacteria that promote or inhibit cyst formation in Alexandrium from seawater samples collected from the $5 \mathrm{~m}$ depth layer at Stn 11 in 1999. Each seawater sample was first filtered through a glass fiber filter $(\mathrm{GF} / \mathrm{F})$ and then through a $0.8 \mu \mathrm{m}$ Millipore or $0.1 \mu \mathrm{m}$ Nuclepore filter. The 0.1 to $0.8 \mu \mathrm{m}$ size fraction was considered to be the fraction containing the bulk of the planktonic bacteria (BF) and the $<0.1 \mu \mathrm{m}$ size fraction to be the 'bacteria-free' fraction (BFF). Using these fraction, MPN values of Alex-CFPB and Alex-CFIB in the seawater samples were calculated from the numbers of Alex-CFPB- and Alex-CFIBpositive wells using the method of Adachi et al. (1999).

Bioassay for enumeration of Alexandrium growthpromoting and -inhibiting bacteria. The numbers of Alexandrium growth-promoting bacteria (Alex-GPB) and growth-inhibiting bacteria (Alex-GIB) were determined by the MPN bioassay reported by Yoshinaga et al. (1995) in order to clarify the relationships between the fluctuations in abundance of Alex-CFIB and those of Alex-GPB and Alex-GIB. The details of this method were described in Adachi et al. (1999).

Colony counts of Alex-CFIB and -CFPB. Seawater samples were diluted serially from $10^{-1}$ to $10^{-3}$ with sterilized seawater. One hundred microliters of these diluted seawater samples were spread onto FeTY agar plates (trypticase pepton $0.5 \mathrm{~g} \mathrm{l}^{-1}$, yeast extract $0.05 \mathrm{~g}$ $\mathrm{l}^{-1}$, Fe-citrate $0.01 \mathrm{~g} \mathrm{l}^{-1}$, agar $15 \mathrm{~g} \mathrm{l}^{-1}, 80 \%$ seawater) and incubated at $20^{\circ} \mathrm{C}$ for 1 mo in the dark. Colony forming units (CFU) in the seawater samples were 
determined by counting colonies formed on the FeTY agar plates. About 50 colonies (diameter about $1 \mathrm{~mm}$ each) were randomly chosen from colonies derived from each seawater sample. Each colony was suspended in $100 \mu \mathrm{l}$ of the autoclaved seawater that had been poured into the wells of 48-well disposable sterilized tissue culture microplates (Iwaki Co., Ltd, Funabashi, Chiba, Japan). No bacterial suspension was added to 16 wells containing autoclaved seawater as a control. In parallel, cultures of 6ax and TNY7 that had reached the phase of mid-exponential growth were adjusted to a concentration of $5.0 \times 10^{3}$ cells ml ${ }^{-1}$ with $\mathrm{f} / 2$ medium and mixed together. Two hundred microliters of the mixed algal cell suspension were inoculated into the microwells containing the bacterial suspensions or controls of autoclaved seawater. The microplates were incubated for 1 mo under the conditions described above. After the incubation, the number of whole cysts formed in each well was counted under an inverted microscope IX-FLA (Olympus). Colonies that led to the formation of 3 times more cysts and one-third fewer cysts than those formed in bacteria-free wells were tentatively regarded as 'AlexCFPB' and 'Alex-CFIB', respectively. The isolation efficiency of each bacterium was obtained as the ratio of the number of Alex-CFIB (or Alex-CFPB) to the number of tested colonies. $\mathrm{CFU}$ of each seawater sample multiplied by the isolation efficiency of the Alex-CFIB and Alex-CFPB gives the number of Alex-CFIB and Alex-CFPB by colony counts, respectively.

Isolation of Alex-CFIB. In order to isolate the dominant bacterial strains of the Alex-CFIB population in the field, supernatants from the MPN-positive wells that had contained BF diluted as much as possible were diluted serially from $10^{-1}$ to $10^{-3}$ with autoclaved seawater. One hundred microliters of these diluted fractions were spread onto FeTY agar plates and incubated at $20^{\circ} \mathrm{C}$ for $1 \mathrm{mo}$ in the dark. Each colony (diameter about $1 \mathrm{~mm}$ ) formed on the FeTY agar plate was screened for isolation of Alex-CFIB according to the method described above. Colonies from field seawater samples that were diluted with autoclaved seawaters as much as possible were also screened. Colonies that caused the Alexandrium catenella cells to form onethird fewer cysts than those formed in bacteria-free wells were selected and streaked onto FeTY agar plates and incubated at $20^{\circ} \mathrm{C}$ for 3 wk under dark conditions. More than 500 colonies were screened using the method described above. Each colony was rescreened using the method described above. Colonies that caused the $A$. catenella cells to form one-third fewer cysts than those formed in bacteria-free wells were tentatively regarded as 'Alex-CFIB'. Tentative 'cyst formation-inhibiting activity' (CFIA) was calculated by the following formula: CFIA = (cyst number in bacteria-free wells - cyst number in wells with bacte$\mathrm{ria} /$ cyst number in bacteria-free wells.

Polymerase chain reaction (PCR) amplification of the 16S rDNA of Alex-CFIB. The bacterial genome DNA was extracted using the method reported by Yoshinaga et al. (1998). The almost complete 16S rDNAs were PCR amplified using the 27F primer (5'AGAGTTTGATC(AC)TGGCTCAG-3') and 1492R primer (5'-ACGG(CT)TACCTTGTTACGACTT-3'), which are complementary to the $5^{\prime}$ end and $3^{\prime}$ end of the prokaryotic 16S rDNA, respectively. Amplifications were performed as previously described by Adachi et al. (1996) using a DNA Thermal Cycler TP2000 (TaKaRa Biomedicals, Osaka, Japan), with 30 thermal cycles of $94^{\circ} \mathrm{C}$ for $1 \mathrm{~min}, 60^{\circ} \mathrm{C}$ for $1 \mathrm{~min}$ and $72^{\circ} \mathrm{C}$ for 3 min with a final elongation step of $7 \mathrm{~min}$ at $72^{\circ} \mathrm{C}$. Reactions contained a $100 \mu \mathrm{l}$ mixture of $2.5 \mathrm{U}$ TaKaRa Taq polymerase (TaKaRa Biomedicals), $10 \mathrm{mM}$ each of deoxy (d) ATP, dCTP, dGTP and dTTP, $1 \times$ reaction buffer (TaKaRa Biomedicals), and $2 \mathrm{mM} \mathrm{MgCl}_{2}$ and 100 pmol each of primer. Completed amplifications were extracted once with chloroform, and the amplified DNA was precipitated with ethanol at $-20^{\circ} \mathrm{C}$. The precipitates were re-suspended in TE solution $(10 \mathrm{mM}$ Tris-HCl pH 8.0 and 1 mM EDTA pH 8.0) and stored at $-20^{\circ} \mathrm{C}$. To estimate yield and purity of PCR products, the precipitated DNA was electrophoresed through $1.5 \%$ agarose S (Nippon Gene, Tokyo, Japan) gel using Tris-acetate-EDTA (TAE) buffer (Sambrook et al. 1989) and quantified by Genequant II (AmershamPharmacia). Two micrograms of the DNA was then digested with 1 of 4 restriction endonucleases: MboI, Hha I (TaKaRa Biomedicals), RsaI (Toyobo, Osaka, Japan) and Bst UI (New England Biolabs, Inc., Beverly, MA, USA) according to the recommendations of the manufacturer. Restriction fragments were resolved by electrophoresis through 4\% NuSieve 3:1 agarose (FMC BioProducts, Rockland, ME, USA). Agarose gels were stained with ethidium bromide and photographed according to standard methods (Sambrook et al. 1989).

PCR direct sequencing and phylogenetic analysis of the 16S rDNA. The excess deoxy nucleotide triphosphate (dNTP) and the remaining primers in PCR products were removed by using a GeneClean III Kit according to the recommendations of the manufacturer (Bio101, Vista, CA, USA). The purified products were directly sequenced by using a BigDye Terminator Cycle Sequencing FS Ready Reaction Kit (PE Biosystems, Osaka, Japan), with bacterial universal 27F primer, EUB338F primer (5'-ACTCCTACGGGAGGCAGC-3'), EUB338R primer (5'-GCTGCCTCCCGTAGGAGT-3'), BAC514F primer (5'-CGTGCCAGCAGCCGCGGTAAT-3'), BAC514R primer (5'-ATTACCGCGGCTGCTGGCACG-3'), BAC785R primer (5'-GACTACCAGGG- 
TATCTAATCC-3'), BAC1059F primer (5'-GTCGTCAGCTCGTGYYGTGA-3'), BAC1059R primer (5'TCACRRCACGAGCTGACGAC-3'), BAC1375F primer (5'-CGGTGAATACGTTCCCGG-3'), BAC1375R primer (5'-CCGGGAACGTATTCACCG-3') and 1492R primer. The number in each primer name shows the corresponding position in the Escherichia coli 16S rDNA. Almost the entire 16S rDNA sequences were aligned to various bacterial 16S rDNA sequences obtained from the European Molecular Biology Laboratory (EMBL), GenBank and DNA Data Base of Japan (DDBJ) databases using the software ClustalW (v. 1.6; EMBL, Heidelberg, Germany). Distances were inferred from sequences by using the 1-parameter model of Jukes \& Cantor (1969). Branch lengths of phylogenetic trees were evaluated by using the neighbor-joining (NJ) method (Saitou \& Nei 1987). Bootstrap analyses of 1000 replicates were carried out with ClustalW.

Determination of activity of representative AlexCFIB. Autoclaved seawater $(4.5 \mathrm{ml})$ from Uranouchi Inlet, Kochi, Japan was poured into each well of 6 -well disposable sterilized tissue culture microplates (Iwaki Co., Ltd; total of 8 plates). Alex-CFIB KF99511-21 (>10 ${ }^{8}$ cells $\mathrm{ml}^{-1}$, late log phase; see Table1) preincubated in the FeTY liquid medium, which had a strong CFIA and belonged to the ribotype Id as described later, was diluted with the FeTY liquid medium to $4.5 \times 10^{7}$ cells $\mathrm{ml}^{-1}$. Three microliters of the diluted bacterial suspension were inoculated at an initial density of $10^{4}$ cells $\mathrm{ml}^{-1}$ into all the wells of 4 microplates containing the autoclaved seawater. The same volume $(3 \mu \mathrm{l})$ of the FeTY liquid medium was added to all the wells of the other 4 microplates as a bacteria-free control. Nine milliliters of each culture of Alexandrium catenella TB93 and TNY7 at the mid-exponential growth phase that had been adjusted to a concentration of $3.0 \times 10^{3}$ cells $\mathrm{ml}^{-1}$ with sterile $\mathrm{f} / 2$ medium were added to all 8 plates, mixed gently and incubated at $20^{\circ} \mathrm{C}$ for 1 mo under the conditions described above. After incubation for $0,3,7$, 14 and $21 \mathrm{~d}$, cysts of $A$. catenella cells in 6 wells of 1 plate containing bacteria and 1 bacteria-free plate were counted under an IX-FLA inverted microscope (Olympus). On the same days, the culture material was removed from the wells. Then the growth of the cultures of $A$. catenella in the 6 wells was monitored by counting under an IX-FLA inverted microscope (Olympus) as well as by measuring in vivo autofluorescence excited by blue light using a Turner 10-AU Fluorometer (Turner Designs Co.). Total bacteria in each culture with bacteria were monitored by the method of Porter \& Feig (1980). After measuring the in vivo fluorescence, the cultures were centrifuged at $1500 \times g$ for $10 \mathrm{~min}$. The culture supernatants were filtered through $0.2 \mu \mathrm{m}$ cellulose acetate filters (Advantec Inc., Tokyo, Japan). Reactive phosphate, nitrate/nitrite and ammonium con- centrations of these samples were determined by means of a TRAACS-800 ${ }^{\mathrm{TM}}$ autoanalyzer (Bran Luebbe, Tokyo, Japan) according to the recommendations of the manufacturer. Total cellular phosphorus was assayed using a modification of the method of Anderson \& Lindquist (1985). The centrifuged cells from about $5 \mathrm{ml}$ of culture in each well were suspended in 20 $\mathrm{ml}$ of artificial seawater $(550 \mathrm{mM} \mathrm{NaCl}, 30 \mathrm{mM}$ $\mathrm{MgSO}_{4} 7 \mathrm{H}_{2} \mathrm{O}, 2 \mathrm{mM} \mathrm{NaHCO} 3$ ). To the solution was added $3.2 \mathrm{ml}$ of potassium persulfate solution $(0.185 \mathrm{M}$ $\mathrm{K}_{2} \mathrm{~S}_{2} \mathrm{O}_{8}$ and $\left.0.25 \mathrm{M} \mathrm{NaOH}\right)$. The solution was then autoclaved for $30 \mathrm{~min}$ at $121^{\circ} \mathrm{C}$. After cooling, the solution was filtered through a $0.8 \mu \mathrm{m}$ Filter Unit MILLEX-AA (Millipore), and reactive phosphate was determined using a TRAACS- $800^{\mathrm{TM}}$ as described above. The total cellular nitrogen was assayed according to the method described below. The harvested cells from about $5 \mathrm{ml}$ of culture in each well were suspended in $3 \mathrm{ml}$ of artificial seawater. One milliliter of PEROX (0.1 $\mathrm{M} \mathrm{K}_{2} \mathrm{~S}_{2} \mathrm{O}_{8}, 0.6 \mathrm{M}$ $\mathrm{NaOH}$ ) was added to the solution. The solution was autoclaved for $30 \mathrm{~min}$ at $121^{\circ} \mathrm{C}$. After cooling, $1 \mathrm{ml}$ of 1.5 $\mathrm{M} \mathrm{HCl}$ was added to the solution and filtered through a $0.8 \mu \mathrm{m}$ Filter Unit MILLEX-AA (Millipore). The solution was diluted with artificial seawater and $2 \mathrm{ml}$ of $1 \mathrm{M}$ Tris was added. The nitrate and nitrite concentrations of the solutions were determined using a TRAACS- $800^{\mathrm{TM}}$ autoanalyzer (Bran Luebbe). Encystment efficiency was calculated using the following formula: Encystment efficiency $=2 N_{\mathrm{c}} / N+2 N_{\mathrm{c}}$, where $N$ is the number of vegetative cells and $N_{\mathrm{c}}$ is the number of cysts). Vegetative growth and nutrient concentration in cultures with bacteria or without bacteria were statistically compared by 2-way ANOVA (Sokal \& Rohlf 1995).

\section{RESULTS}

\section{Alexandrium tamarense blooms and environmental conditions}

Water temperature at $5 \mathrm{~m}$ depth of Stn 11 increased from ca $10^{\circ} \mathrm{C}$ in February to the annual maximum of 25 to $26^{\circ} \mathrm{C}$ in August with a steady decrease after September (Fig. 1C). Alexandrium tamarense was first observed at a seawater temperature of $11^{\circ} \mathrm{C}$ in 1999 and peaked at around 13 to $15^{\circ} \mathrm{C}$ in the middle of April (Fig. 1A,C). A maximum density of $3.53 \times 10^{2}$ cells $1^{-1}$ occurred at the $5 \mathrm{~m}$ depth layer on April 19, 1999. Blooms gradually declined from the middle of May in 1999 (Fig. 1A). Since A. tamarense was densely distributed at $5 \mathrm{~m}$ depth during the period of bloom in 1997 to 1999 (data not shown), samples for estimating bacterial effects were collected from $5 \mathrm{~m}$ depth. Salinity ranged between a high of 33.0 in late winter and a low of 30.2 on September 16, 1999 (Fig. 1C). Nutrient concentra- 

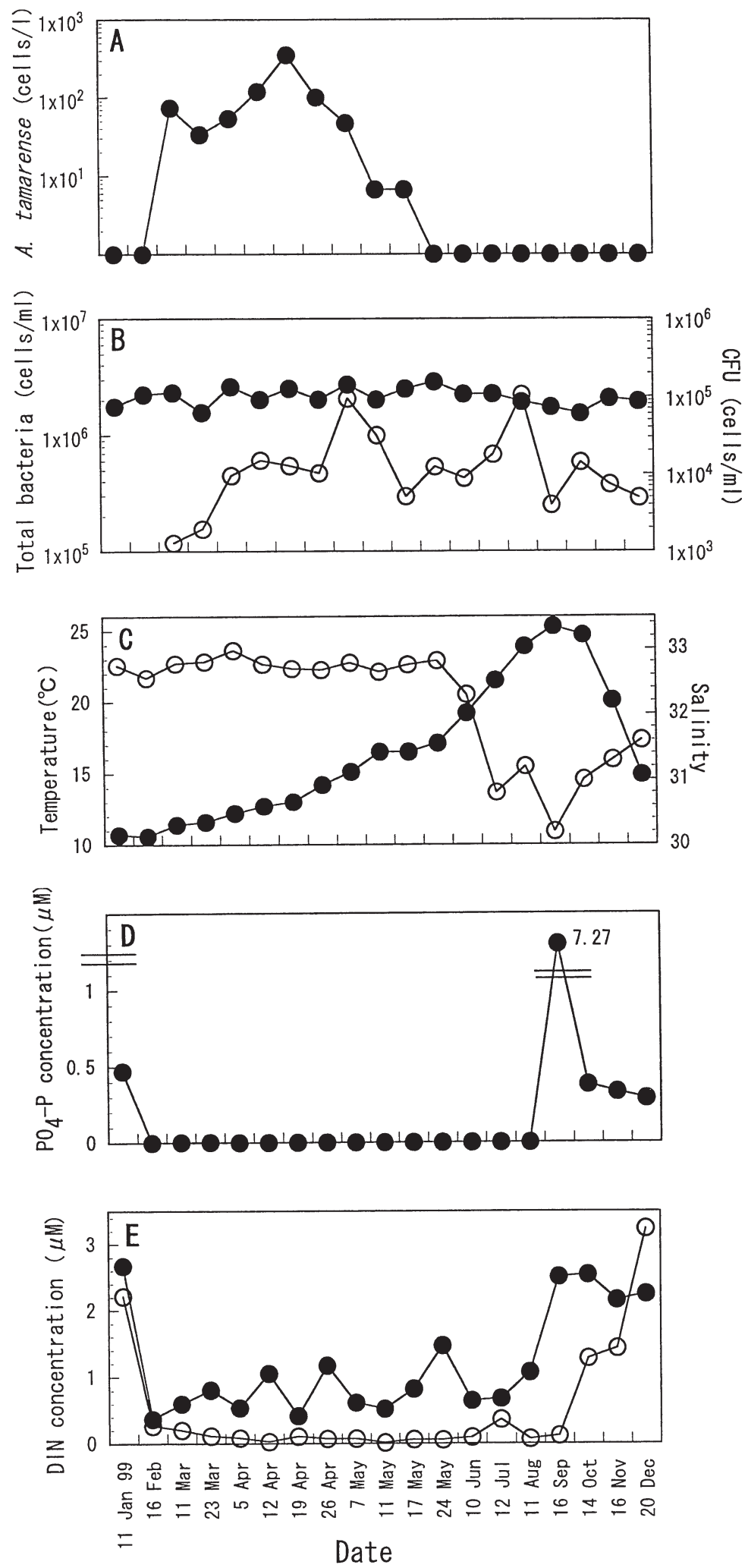

Fig. 1. Seasonal changes of (A) Alexandrium tamarense density, (B) total bacteria (O) and colony-forming units (O), (C) temperature (-) and salinity (O), (D) inorganic nutrient phosphate, and (E) ammonium (O) and nitrate/nitrite (O) at $5 \mathrm{~m}$ depth at Stn 11 in 1999 tions decreased during the early bloom development periods and then became constant at a low level until the beginning of summer (Fig. 1D,E). A high concentration of phosphorus $(7.27 \mu \mathrm{M})$ was observed on September 16, 1999. The total number of bacteria fluctuated little $\left(1.54 \times 10^{6}\right.$ to $2.87 \times 10^{6}$ cells $\mathrm{ml}^{-1}$ ) over the observed period (Fig. 1B). CFU ranged from $3.98 \times 10^{3}$ cells ml ${ }^{-1}$ to $1.04 \times 10^{5}$ cells $\mathrm{ml}^{-1}$ (Fig. $1 \mathrm{~B}$ ).

\section{Abundance of Alex-CFIB, -CFPB, -GIB and -GPB}

Alex-CFIB in the seawater samples were detected by the MPN bioassay on March 23 and May 7, 1999, during the bloom period when a low density of Alexandrium tamarense $\left(<10^{3}\right.$ cells $\mathrm{l}^{-1}$ ) was observed (Fig. 2A,B). After the bloom period, Alex-CFIB were detected by MPN from June 10 to October 14, 1999 (Fig. 2B). The highest concentration of Alex-CFIB by MPN $\left(9.25 \times 10^{2}\right.$ cells $\left.\mathrm{ml}^{-1}\right)$ was observed on September 16, 1999 (Fig. 2B), when A. tamarense cells were not detected (Fig. 2A). The number of cells of Alex-CFIB by MPN and the abundance of $A$. tamarense did not show positive correlation $(y=$ $50.2-5.39 \times 10^{-2} X, \mathrm{r}^{2}=0.0188, \mathrm{P}_{\beta}=0.600,-0.268$ $<\beta<0.160$, where $\beta$ is the slope). Alex-CFIB, determined by the colony-counting method (Alex-CFIB by CC), were first observed on April 5, 1999, during the bloom-developing period and fluctuated from $1.95 \times 10^{2}$ cells ml ${ }^{-1}$ to $2.63 \times$ $10^{3}$ cells ml-1 and then decreased on August 11, 1999. Alex-CFIB by CC increased on September 16,1999 , reached $3.55 \times 10^{2}$ cells $\mathrm{ml}^{-1}$ on October 14,1999, and then decreased on November 16, 1999 (Fig. 2B). Alex-CFIB by CC also did not correlate with $A$. tamarense $(y=60.8-1.38 \times$ $10^{-2} x, \mathrm{r}^{2}=0.0278, \mathrm{P}_{\beta}=0.522,-0.0580<\beta<$ 0.0310). Alex-CFPB were counted by the MPN bioassay on March 11 and April 5, when the bloom was developing, and peaked at $4.35 \times$ $10^{2}$ cells $\mathrm{ml}^{-1}$ on May 11, 1999 (Fig. 2C), when the bloom was declining. After the bloom, the next peak of Alex-CFPB by MPN was observed on November 16, 1999, when A. tamarense cells were not detected (Fig. 2C). Alex-CFPB by CC were only detected on August 11 and September 16, 1999 (Fig. 2C). The number of cells of neither Alex-CFPB by MPN nor Alex-CFPB by CC significantly correlated with the abundance of Alexandrium sp. Alex-GPB fluctuated from $7.33 \times 10^{1}$ cells ml $^{-1}$ to $6.13 \times 10^{2}$ cells ml ${ }^{-1}$ during the bloom period, except for the peak bloom 

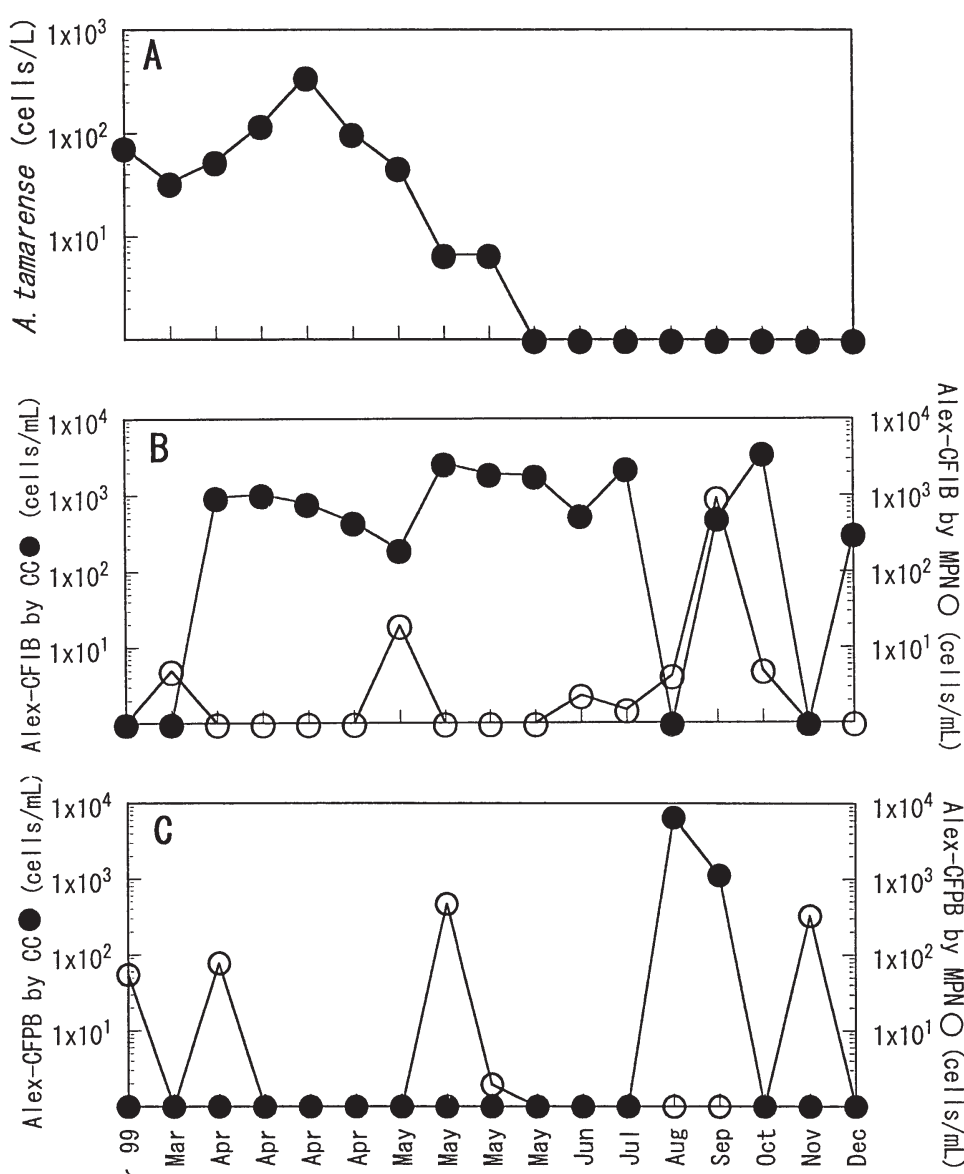

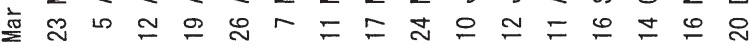
二

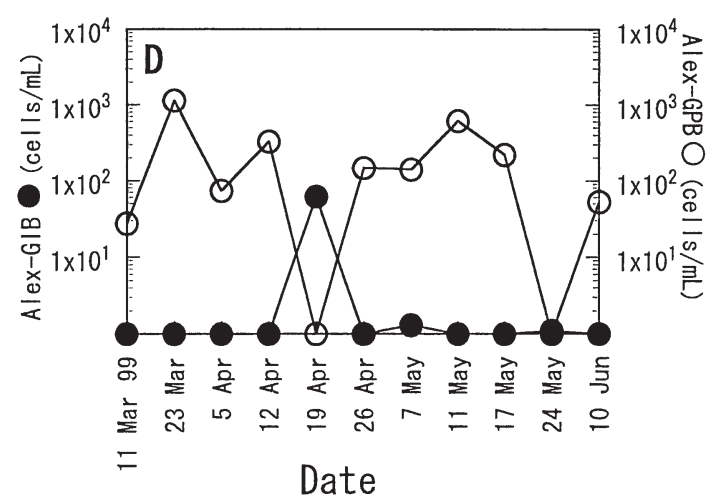

Fig. 2. Fluctuations of (A) Alexandrium tamarense density, (B) the number of Alexandrium cyst formation-inhibiting bacteria (AlexCFIB) determined by the most probable number (MPN) bioassay (O) and Alex-CFIB determined by colony counting $(\mathbf{O})$, (C) the number of Alexandrium cyst formation-promoting bacteria (AlexCFPB) by the MPN bioassay (O) and Alex-CFPB by colony counting ( ), and (D) the number of Alexandrium growth-promoting bacteria (Alex-GPB) (O) and Alexandrium growth-inhibiting bacteria (Alex-GIB) (@) at Stn 11 in Hiroshima Bay

period (April 19) and the bloom disintegration period (May 24) (Fig. 2D). Alex-GIB were only detected during the peak bloom period (Fig. 2D).

\section{Isolation of Alex-CFIB}

Twelve and 20 strains of Alex-CFIB were isolated from colonies obtained from the MPN-positive wells and from field seawater samples, respectively, termed $\mathrm{KC}$ and $\mathrm{KF}$ strains after their origin, respectively: $\mathrm{KC}$, from the MPN culture supernatants, and KF, from the field seawater samples (Table 1). The CFIA of each isolate, which was tentatively determined, ranged from 0.74 to 1.0 (Table 1 ).

\section{S rDNA-based RFLP analysis of Alex-CFIB}

PCR amplification of the 16S rDNA from the 32 isolates of Alex-CFIB resulted in a single product of approximately 1500 base pairs (bp) (data not shown). A total of 3, 4, 5 and 2 different RFLP types were detected using the restriction enzymes MboI, HhaI, RsaI and Bst U1, respectively (data not shown). Taken together, our results reveal 5 ribotypes among the 32 isolates of the Alex-CFIB tested. Four types among them showed similar patterns and were named ribotype I (Ia to Id). Thirty-one isolates among the 32 isolates belonged to the ribotype I (Table 1). Among the 31 isolates of ribotype I, 20 isolates belonged to the ribotype Id. These isolates of ribotype Id were isolated from the seawater samples taken throughout the year. The other type, which showed quite different patterns from those of ribotype I, was termed ribotype II.

\section{S rDNA-based phylogenetic analysis of Alex-CFIB}

Almost the entire 16S rDNA sequence of an isolate from each ribotype was sequenced. Fig. 3 shows a phylogenetic tree indicating that the isolates of ribotypes Ia to Id and II fell within the $\gamma$ subdivision of the class Proteobacteria. Ribotypes Ia to Id are closely related to each other and are clustered within the Alteromonas group. Ribotype II was clustered in the Vibrio group.

\section{Determination of activity of Alex-CFIB}

When the activity of the ribotype Id isolate (KF99511-21, Table 1) was analyzed using the 6well microplate approach, differences in algal growth were not significant in cultures with and without bacteria $(F=1.06, \mathrm{P}=0.36>0.05)$ (Fig. $4 \mathrm{~A}, \mathrm{~B})$. In wells to 
Table 1. List of Alexandrium cyst formation-inhibiting bacteria (Alex-CFIB). BFW: bacteria-free wells; BW: wells inoculated with bacteria; CFIA: cyst formation-inhibiting activity = (cyst number in bacteria-free wells - cyst number in wells with bacteria)/cyst number in bacteria-free wells; SW: seawater; sup.: supplement

\begin{tabular}{|c|c|c|c|c|c|c|c|}
\hline \multirow[t]{2}{*}{ Strain } & \multirow{2}{*}{$\begin{array}{c}\text { Sampling } \\
\text { date }(\mathrm{mo} / \mathrm{d} / \mathrm{yr})\end{array}$} & \multirow{2}{*}{$\begin{array}{l}\text { Isolation } \\
\text { origin }\end{array}$} & \multirow[t]{2}{*}{ Dilution } & \multicolumn{2}{|c|}{ Cyst number } & \multirow[t]{2}{*}{ CFIA } & \multirow[t]{2}{*}{ Ribotype } \\
\hline & & & & in $\mathrm{BFW}$ & in BW & & \\
\hline KC 98716-12 & 7/16/1998 & Culture sup. & $10^{-1}$ & $200 \pm 56$ & 2.0 & 0.99 & Ia \\
\hline KC 98716-13 & 7/16/1998 & Culture sup. & $10^{-1}$ & $200 \pm 56$ & 3.0 & 0.98 & Ia \\
\hline KC 98716-15 & 7/16/1998 & Culture sup. & $10^{-1}$ & $200 \pm 56$ & 0.0 & 1.00 & Ia \\
\hline KC 98716-16 & $7 / 16 / 1998$ & Culture sup. & $10^{-1}$ & $200 \pm 56$ & 1.0 & 0.99 & Ia \\
\hline KC 98716-17 & 7/16/1998 & Culture sup. & $10^{-1}$ & $200 \pm 56$ & 5.0 & 0.97 & Ia \\
\hline KC 98716-18 & 7/16/1998 & Culture sup. & $10^{-1}$ & $200 \pm 56$ & 4.0 & 0.98 & Ia \\
\hline KC 98716-19 & 7/16/1998 & Culture sup. & $10^{-1}$ & $200 \pm 56$ & 1.0 & 0.99 & Ia \\
\hline KC 98716-110 & 7/16/1998 & Culture sup. & $10^{-1}$ & $200 \pm 56$ & 7.0 & 0.96 & Ia \\
\hline KC 98716-111 & 7/16/1998 & Culture sup. & $10^{-1}$ & $200 \pm 56$ & 1.0 & 0.99 & Ia \\
\hline KC 98716-14 & 7/16/1998 & Culture sup. & $10^{-1}$ & $200 \pm 56$ & 3.0 & 0.98 & $\mathrm{Ib}$ \\
\hline KC 98716-11 & 7/16/1998 & Culture sup. & $10^{-1}$ & $200 \pm 56$ & 6.0 & 0.97 & Ic \\
\hline KF 99419-21 & 4/19/1999 & Field SW & $10^{-2}$ & $25 \pm 9.8$ & 1.3 & 0.95 & Id \\
\hline KF 994192-22 & 4/19/1999 & Field SW & $10^{-2}$ & $25 \pm 9.8$ & 0.67 & 0.97 & Id \\
\hline KF 99507-21 & 5/7/1999 & Field SW & $10^{-2}$ & $25 \pm 9.8$ & 0.67 & 0.97 & Id \\
\hline KF 99511-21 & 5/11/1999 & Field SW & $10^{-2}$ & $25 \pm 9.8$ & 0.33 & 0.99 & Id \\
\hline KF 99511-22 & $5 / 11 / 1999$ & Field SW & $10^{-2}$ & $25 \pm 9.8$ & 0.33 & 0.99 & Id \\
\hline KF 99511-23 & $5 / 11 / 1999$ & Field SW & $10^{-2}$ & $25 \pm 9.8$ & 1.7 & 0.93 & Id \\
\hline KF 99524-21 & $5 / 24 / 1999$ & Field SW & $10^{-2}$ & $25 \pm 9.8$ & 0.0 & 1 & Id \\
\hline KF 99524-22 & $5 / 24 / 1999$ & Field SW & $10^{-2}$ & $25 \pm 9.8$ & 0.33 & 0.99 & Id \\
\hline KF 99524-23 & $5 / 24 / 1999$ & Field SW & $10^{-2}$ & $25 \pm 9.8$ & 0.33 & 0.99 & Id \\
\hline KF 99524-24 & $5 / 24 / 1999$ & Field SW & $10^{-2}$ & $25 \pm 9.8$ & 0.0 & 1 & Id \\
\hline KF 99610-21 & 6/10/1999 & Field SW & $10^{-2}$ & $47 \pm 14$ & 2.3 & 0.95 & Id \\
\hline KF 99712-21 & 7/12/1999 & Field SW & $10^{-2}$ & $47 \pm 14$ & 4.0 & 0.91 & Id \\
\hline KF 99712-22 & 7/12/1999 & Field SW & $10^{-2}$ & $47 \pm 14$ & 6.3 & 0.86 & Id \\
\hline KF 99916-21 & 9/16/1999 & Field SW & $10^{-2}$ & $47 \pm 14$ & 2.0 & 0.96 & Id \\
\hline KF 99916-22 & 9/16/1999 & Field SW & $10^{-2}$ & $47 \pm 14$ & 12 & 0.74 & Id \\
\hline KF 99916-23 & 9/16/1999 & Field SW & $10^{-2}$ & $47 \pm 14$ & 1.7 & 0.96 & Id \\
\hline KF 99916-24 & 9/16/1999 & Field SW & $10^{-2}$ & $47 \pm 14$ & 2.7 & 0.94 & Id \\
\hline KF 991010-21 & $10 / 10 / 1999$ & Field SW & $10^{-2}$ & $47 \pm 14$ & 6.7 & 0.86 & Id \\
\hline KF 991010-22 & $10 / 10 / 1999$ & Field SW & $10^{-2}$ & $47 \pm 14$ & 4.3 & 0.91 & Id \\
\hline KF 991010-23 & $10 / 10 / 1999$ & Field SW & $10^{-2}$ & $47 \pm 14$ & 3.7 & 0.92 & Id \\
\hline KC 98716-112 & $7 / 16 / 1998$ & Culture sup. & $10^{-1}$ & $47 \pm 14$ & 4.0 & 0.98 & II \\
\hline
\end{tabular}

which the bacteria had been added, the total bacteria

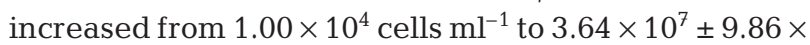
$10^{5}$ (mean $\pm \mathrm{SD}$ ) cells $\mathrm{ml}^{-1}$ (Fig. 4E). The cyst yield in wells inoculated with and without the bacteria reached

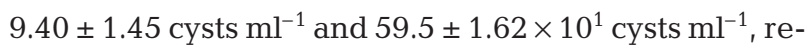
spectively, after incubation for $7 \mathrm{~d}$ (Fig. 4C), which showed a significant difference of cyst yield between them $\left(t\right.$-test, $t_{\text {Day7 }}, t_{\text {Day14 }}$ and $t_{\text {Day21 }}=7.55,7.76$ and 16.4, $\mathrm{P}_{\text {Day } 7}, \mathrm{P}_{\text {Day14 }}$, and $\mathrm{P}_{\text {Day21 }}=6.47 \times 10^{-4}, 5.68 \times 10^{-4}$, and $1.54 \times 10^{-5}$, respectively $\left.<0.001\right)$. The encystment efficiency in cultures with and without bacteria was $2.66 \times$ $10^{-3}$ and $1.81 \times 10^{-2}$, respectively, at that time (Fig. 4D). The ratio of the maximum encystment efficiency in cultures with bacteria to that in bacteria-free cultures was 0.147 . When the activities of ribotypes Ia and II were analyzed using the same approach, Alexandrium catenella growth was similar with added bacteria and under bacteria-free conditions, and the maximum cyst yield with added bacteria was less than that without. The ratio of the maximum encystment efficiency in cul- tures to which ribotype Ia and II had been added was 0.297 and 0.521 , respectively.

The concentration of phosphate in wells with the bacteria added was less than that in the bacteria-free wells throughout the incubation period (Fig. 5A). After $3 \mathrm{~d}$ of incubation, the phosphate concentration in bacterial wells dropped to less than $1 \mu \mathrm{M}$. The difference in phosphate concentration, however, was not significant $(F=1.50, \mathrm{P}=0.29>0.05)$. The nitrate/nitrite concentration in the bacterial wells was also less than that in the bacteria-free wells throughout the incubation period (Fig. 5B). The difference was not significant $(F=$ $5.00, \mathrm{P}=0.09>0.05)$. The concentration of ammonium in the bacterial wells and in the bacteria-free wells decreased similarly (Fig. 5C), but the difference was significant $(F=11.5, \mathrm{P}=0.03<0.05)$. Cellular phosphorus in the bacterial wells was slightly higher than that in the bacteria-free wells after $3 \mathrm{~d}$ of incubation and was lower than that in the bacteria-free wells after $7 \mathrm{~d}$ of incubation (Fig. 5D). The difference in cellular 


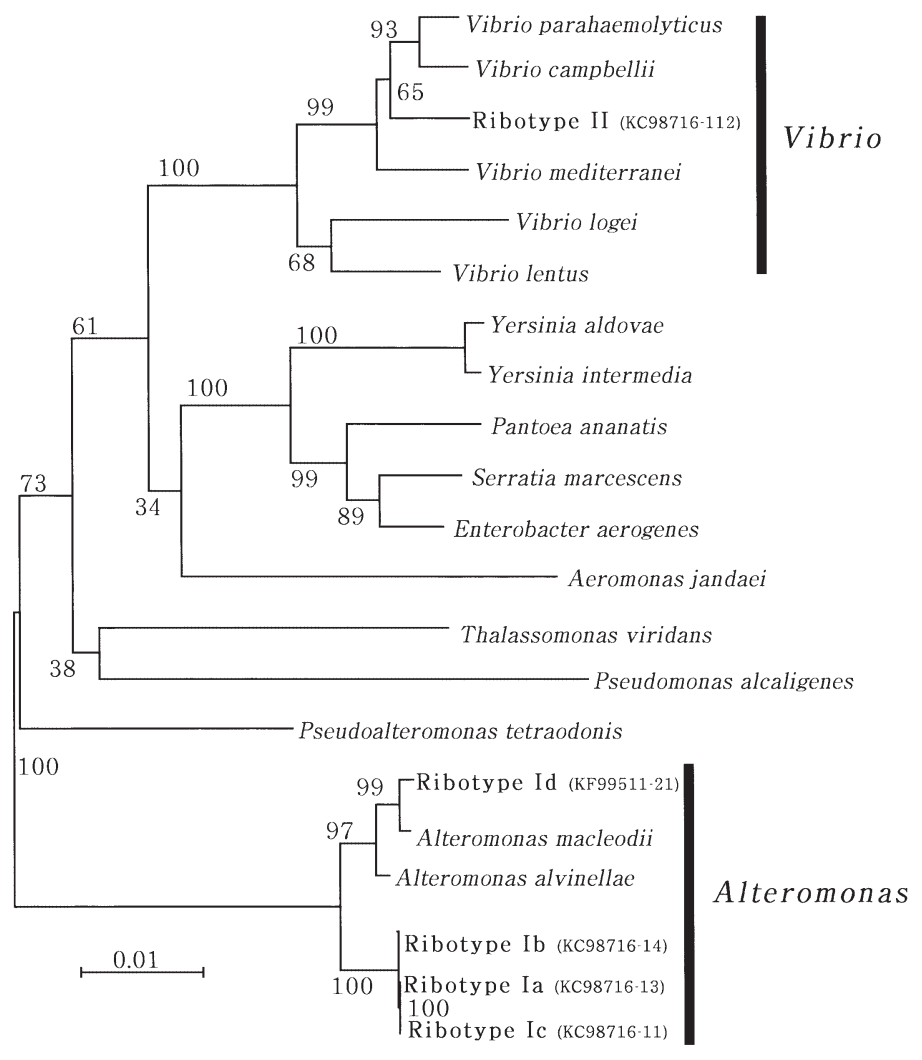

Fig. 3. Molecular phylogenetic tree inferred from almost the entire 16S ribosomal RNA genes (16S rDNA) in Alex-CFIB using the neighbor-joining (NJ) method. Numbers are percentages of 1000 bootstrap repetitions

phosphorus throughout the incubation period was not significant $(F=0.01, \mathrm{P}=0.16>0.05)$. Cellular nitrogen in the bacterial wells remained constant (153 to $213 \mathrm{pg}$ cell $^{-1}$ ) and was not significantly different from that in the bacteria-free wells $(F=2.08, \mathrm{P}=0.22>0.05)$ (Fig. 5E).

\section{DISCUSSION}

\section{Abundance of Alex-CFIB}

Alex-CFIB were detected in seawater sampled from Hiroshima Bay throughout the year by the MPN bioassay as well as by CC, indicating that Alex-CFIB may be ubiquitous in the coastal waters where the toxic dinoflagellate Alexandrium occurs annually. In 1997 and 1998, Alex-CFIB were not detected by MPN when

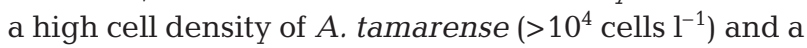
high concentration of Alex-CFPB were observed (Adachi et al. 1999). In contrast, Alex-CFIB were detected by MPN during the bloom period in 1999,

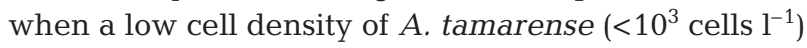

was observed and Alex-CFPB were detected at low levels only. In each MPN microwell containing $\mathrm{BF}$ from natural seawaters, not only Alex-CFIB but also Alex-CFPB probably coexist, so that the MPN of Alex-CFIB in this study may have been underestimated, since the inhibitory effects on encystment may reflect the balance of the effects of both Alex-CFIB and Alex-CFPB in our MPN bioassay. The number of Alex-CFIB detected by $\mathrm{CC}$ was higher than that of Alex-CFIB detected by the MPN bioassay in most seawater samples, which suggests that $\mathrm{CC}$ might be more suitable than MPN counting for the detection of Alex-CFIB in some cases since CC of Alex-CFIB is not affected by the coexisting Alex-CFPB in the seawater samples. All of our laboratory bioassays employed strains of $A$. catenella instead of $A$. tamarense because $A$. tamarense from Hiroshima Bay did not readily form cysts. There is a possibility that the susceptibility of $A$. catenella to Alex-CFIB may be different from that of $A$. tamarense, even if these 2 species are phylogenetically close relatives (Adachi et al. 1996) and form cysts when they are mated with each other (Sako et al. 1990), which may affect the abundance of Alex-CFIB studied in this report. The number of Alex-CFIB might also be affected by the coexisting Alex-GIB in the MPN wells, since the growth in the wells was not monitored in our MPN assay and the CC bioassay. Alex-GIB were detected by our bioassay only during the peak bloom period, which indicates that the number of Alex-CFIB by CC at that time may have been overestimated. Furthermore, we have to consider the possibility that some bacteria may also be directly inhibiting growth or activity of Alex-CFIB in the MPN wells. In order to estimate accurate in situ abundance of Alex-CFIB, quantitative molecular techniques such as a fluorescent in situ hybridization (FISH) should be conducted after the 16S rDNA phylogenies of Alex-CFIB have been determined.

\section{Phylogenetic analysis of Alex-CFIB}

Most of the 32 Alex-CFIB strains isolated from Hiroshima Bay throughout the year belonged to the class Proteobacteria, $\gamma$-subdivision, Alteromonas group, which suggests that this group might be dominant in the Alex-CFIB assemblage in Hiroshima Bay. Ribotypes Ia to Id that are closely related to each other may have a similar mechanism of encystment inhibition. DNA probes that are designed from the common sequences among the ribotype I strains may be useful for the precise detection and enumeration of ribotype I strains in natural seawater. 

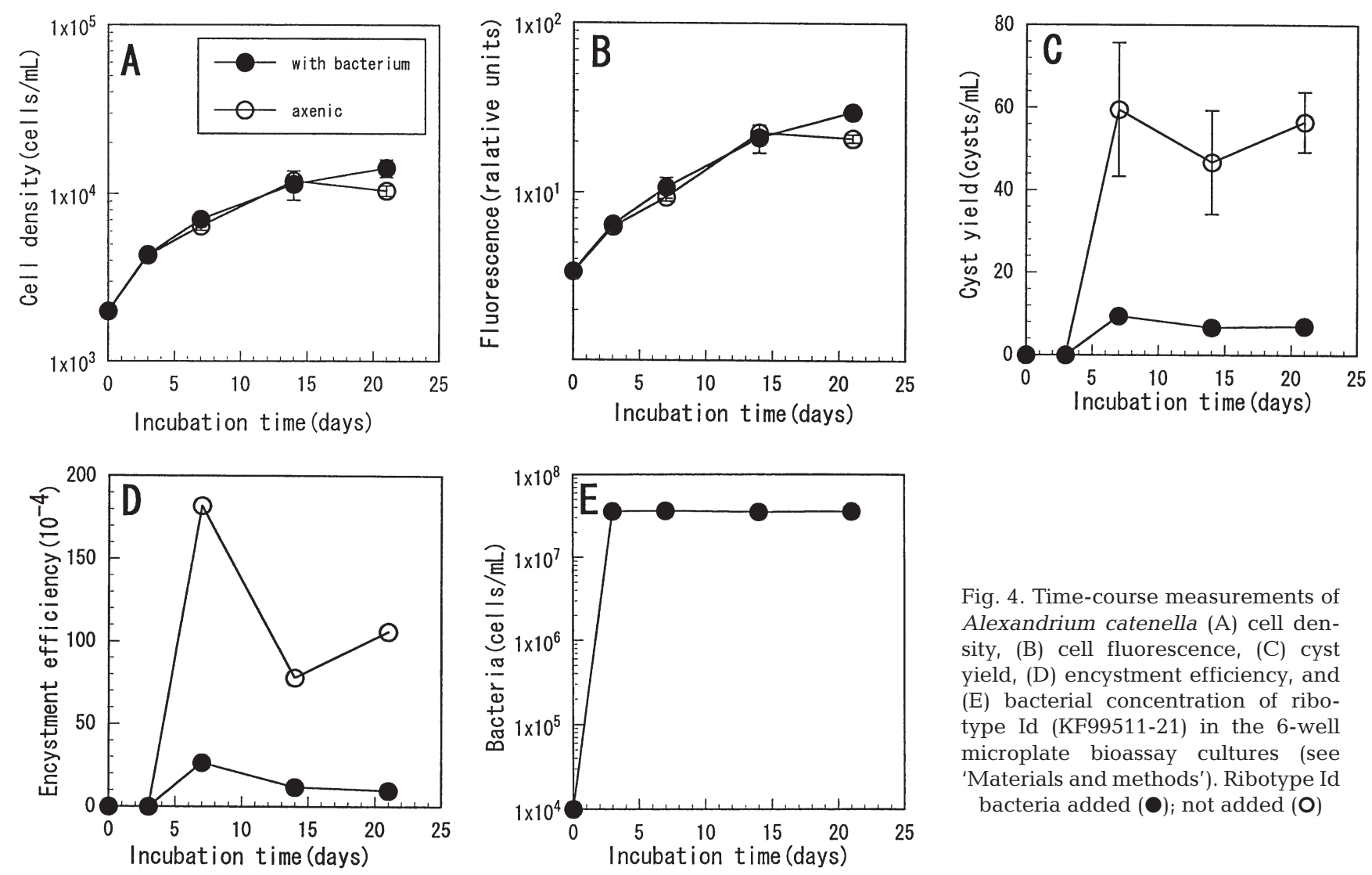

Fig. 4. Time-course measurements of Alexandrium catenella (A) cell density, (B) cell fluorescence, (C) cyst yield, (D) encystment efficiency, and (E) bacterial concentration of ribotype Id (KF99511-21) in the 6-well microplate bioassay cultures (see 'Materials and methods'). Ribotype Id bacteria added (0); not added (0)
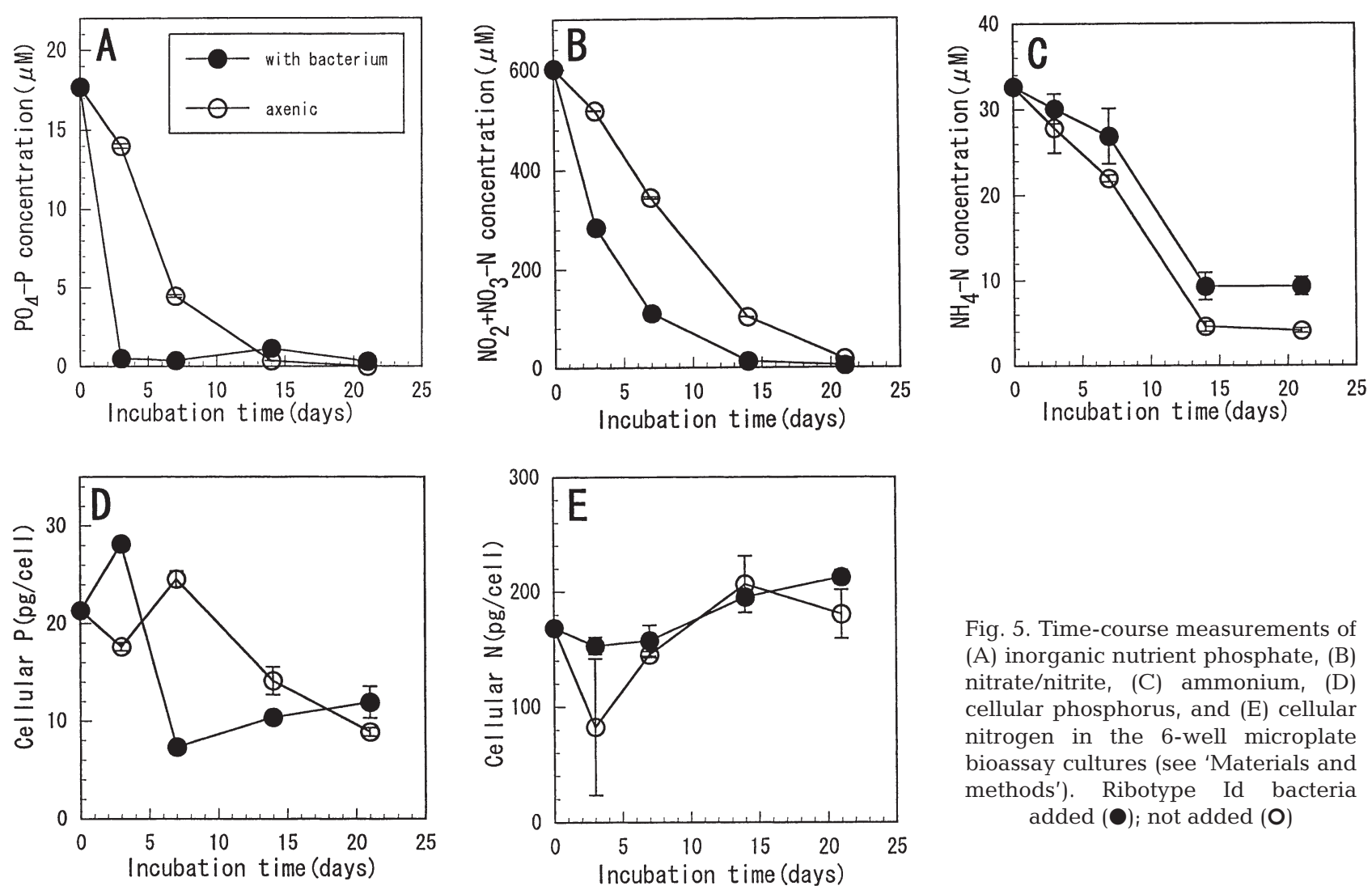

Fig. 5. Time-course measurements of (A) inorganic nutrient phosphate, (B) nitrate/nitrite, (C) ammonium, (D) cellular phosphorus, and (E) cellular nitrogen in the 6-well microplate bioassay cultures (see 'Materials and methods'). Ribotype Id bacteria added (๑); not added (O) 


\section{Activities of Alex-CFIB}

In the 6-well microplate experiments, Alex-CFIB obtained in this study showed no growth-inhibiting activities but did show encystment-inhibiting activities. Alex-CFIB of ribotype I (Alteromonas group), which are possibly dominant in the Alex-CFIB assemblages in Hiroshima Bay and show strong encystment inhibition activites, may play significant roles in the process of encystment and bloom dynamics of Alexandrium in the natural habitat.

It is reported that sexuality in Alexandrium tamarense is controlled by the initial macronutrient availability in batch culture, such as nitrogen and/or phosphorus, and is induced by nitrogen (nitrate/nitrite and ammonium) and/or phosphorus depletion (Anderson et al. 1984). This implies that the addition of macronutrients to batch culture may cause inhibition of cyst formation in some cases. In this report, the addition of Alex-CFIB did not increase the concentration of phosphate, nitrate, nitrite and ammonium, nor of cellular nitrogen or cellular phosphorus, even considering the possibility that our cellular nitrogen and phosphorus presented in Fig. 5D,E may have contained not only algal cellular nitrogen and phosphorus but also 'attached' bacterial nitrogen and phosphorus. This result indicates that the inhibition of encystment by the addition of Alex-CFIB was caused not by the indirect effect of changes in macronutrient concentration (nitrogen, phosphorus) by Alex-CFIB but by an indirect effect of change in micronutrient concentration or a direct effect of a substance produced or excreted by Alex-CFIB under our laboratory conditions.

\section{Trigger of encystment}

In the 6-well microplate experiments, cyst numbers peaked after an incubation of $7 \mathrm{~d}$, indicating that cyst formation mainly occurred within the first week. Considering that it takes about $5 \mathrm{~d}$ to mature from fused cells (planozygotes) to resting cysts (hypnozygotes) (Anderson et al. 1983), most fusion probably occurred within several days after mixing. At that time, macronutrients in the culture supernatant and cellular nitrogen and phosphorus in wells containing BFF were not depleted, which suggests that nutrient depletion was not a trigger of cyst formation in our experiments.

\section{Natural bacteria affect cyst formation in marine phytoplankton}

Recently, bacteria that affect the sexuality of some marine phytoplankton have been isolated from the natural environment. A bacterium that promotes sperm formation of the diatom Coscinodiscus wailesii Gran was isolated from sediment from Harima-Nada (Japan) by Nagai et al. (1994). They determined that the abundance of the bacterium in the sediments determined by MPN bioassay was about $10^{4} \mathrm{cells} \mathrm{ml}^{-1}$ in the natural environment and concluded that the bacterium might play an important role in the process of sperm formation in the field (Nagai \& Imai 1998). Sawayama (1991) and Sawayama et al. (1993) reported that a bacterium isolated from Majero Island in the Pacific Ocean and a bacterium from Lake Tsumoso, Nepal, inhibited the mating reaction of Alexandrium catenella. These bacteria might affect sexual reproduction of natural phytoplankton species in the field, although neither the abundance of the bacterium nor its ecological roles in the field were analyzed. Adachi et al. (1999) observed an abundance of Alex-CFPB in Hiroshima Bay and confirmed a clear positive correlation between the abundance of $A$. tamarense and that of Alex-CFPB. They suggest that Alex-CFPB may play a significant role in the process of encystment and bloom disintegration in the field. Our results in this study show the existence of not only Alex-CFPB but also Alex-CFIB in Hiroshima Bay throughout the year, which suggests that Alex-CFIB as well as Alex-CFPB may play significant roles in the process of encystment and bloom dynamics of Alexandrium in the natural environment.

Acknowledgements. This work was supported by Grants-inAid for Encouragement of Young Scientists (Nos. 09760179 and 11760137) from the Ministry of Education, Science, Sports and Culture of Japan. We thank Drs R. Kondo, N. Nishibori and Y. Sako for providing cultures of Alexandrium catenella. We also thank Dr K. Fukami for valuable advice.

\section{LITERATURE CITED}

Adachi M, Sako Y, Ishida Y (1996) Analysis of Alexandrium (Dinophyceae) species using sequences of the $5.8 \mathrm{~S}$ ribosomal DNA and internal transcribed spacer regions. J Phycol 32:424-432

Adachi M, Kanno T, Matsubara T, Nishijima T, Itakura S, Yamaguchi M (1999) Promotion of cyst formation in the toxic dinoflagellate Alexandrium (Dinophyceae) by natural bacterial assemblages from Hiroshima Bay, Japan. Mar Ecol Prog Ser 191:175-185

Anderson DM, Lindquist NL (1985) Time-course measurements of phosphorus depletion and cyst formation in the dinoflagellate Gonyaulax tamarensis Lebour. J Exp Mar Biol Ecol 86:1-13

Anderson DM, Morel FMM (1979) The seeding of two red tide blooms by the germination of benthic Gonyaulax tamarensis hypnocyst. Estuar Coast Mar Sci 8:279-293

Anderson DM, Wall D (1978) The potential importance of benthic cysts of Gonyaulax tamarensis and Gonyaulax excavata in initiating toxic dinoflagellate blooms. J Phycol $14: 224-234$ 
Anderson DM, Chisholm SW, Watras CJ (1983) Importance of life cycle events in the population dynamics of Gonyaulax tamarensis. Mar Biol 76:179-189

Anderson DM, Kulis DM, Binder BJ (1984) Sexuality and cyst formation in the dinoflagellate Gonyaulax tamarensis: cyst yield in batch cultures. J Phycol 20:418-425

Dale B (1977) Cysts of the toxic red-tide dinoflagellate Gonyaulax excavata (Braarud) Balech from Oslofjorden, Norway. Sarsia 63:29-34

Guillard RR, Ryther JH (1962) Studies of marine planktonic diatoms. 1. Cyclotella nana Hustedt and Detonula confervacea (Cleve) Gran. Can J Mirobiol 8:229-239

Hallegraeff GM (1993) A review of harmful algal blooms and their apparent global increase. Phycologia 32:79-99

Jukes TH, Cantor CR (1969) Evolution of protein molecules. In: Munro HN (ed) Mammalian protein metabolism. Academic Press, New York, p 21-132

Nagai S, Imai I (1998) Enumeration of bacteria in seawater and sediment from the Seto Inland Sea of Japan that promote sperm formation in Coscinodiscus wailesii (Bacillariophyceae). Phycologia 37:363-368

Nagai S, Hori Y, Manabe T, Imai I (1994) Promotion of sperm formation of a giant diatom Coscinodiscus wailesii Gran by a marine bacterium. Fish Sci 60:625-626

Perez CC, Roy S, Levasseur M, Anderson DM (1998) Control of germination of Alexandrium tamarense (Dinophyceae) cysts from the Lower St. Lawrence Estuary (Canada). J Phycol 34:242-249

Pfiester L, Anderson DM (1987) Dinoflagellate reproduction. In: Taylor FJR (ed) Biology of dinoflagellates. Blackwell Scientific Publications, Oxford, p 611-648

Porter KG, Feig YS (1980) The use of DAPI for identifying and counting aquatic microflora. Limnol Oceanogr 25:943-948

Saitou N, Nei M (1987) The neighbor-joining method. A new method for reconstructing phylogenetic trees. Mol Biol Evol 4:406-425

Editorial responsibility: William $\mathrm{Li}$, Dartmouth, Nova Scotia, Canada
Sako Y, Kim CH, Ninomiya H, Adachi M, Ishida Y (1990) Isozyme and cross analysis of mating populations in the Alexandrium catenella/tamarense species complex. In: Granelí E, Sundstrøm B, Edler L, Anderson DM (eds) Toxic marine phytoplankton. Elsevier, New York, p 320-323

Sambrook J, Fritsch EF, Maniatis T (1989) Molecular cloning: a laboratory manual, 2nd edn. Cold Spring Harbor Laboratory Press, Cold Spring Harbor

Sawayama S (1991) Studies on bacterial inhibition for mating of microalgae. Doctoral thesis, Kyoto University

Sawayama S, Sako Y, Ishida Y (1993) New inhibitor for mating reaction of Alexandrium catenella produced by marine Alteromonas sp. Nippon Suisan Gakkaishi 59: 291-294

Sokal RR, Rohlf FJ (1995) Biometry, 3rd edn. WH Freeman \& Co., New York

Shumway SE (1993) A review of the effects of algal blooms on shellfish and aquaculture. J World Aquac Soc 21:65-104

Steidinger KA (1975) Basic factors influencing red tides. In: LoCicero VR (ed) Toxic dinoflagellate blooms. Elsevier, Wakefield, p 153-162

Turpin DH, Dobell PER, Taylor FJR (1978) Sexuality and cyst formation in Pacific strains of the toxic dinoflagellate Gonyaulax tamarense. J Phycol 14:235-238

Yoshimatsu S (1981) Sexual reproduction of Protogonyaulax catenella in culture. Bull Plankton Soc Japan 28:131-139

Yoshinaga I, Kawai T, Takeuchi T, Ishida Y (1995) Distribution and fluctuation of bacteria inhibiting the growth of a marine red tide phytoplankton Gymnodinium mikimotoi in Tanabe Bay (Wakayama Pref., Japan). Fish Sci 61:780-786

Yoshinaga I, Kim MC, Katanozaka N, Imai I, Uchida A, Ishida Y (1998) Population structure of algicidal marine bacteria targeting the red tide forming alga Heterosigma akashiwo (Raphidophyceae), determined by restriction fragment length polymorphism analysis of the bacterial $16 \mathrm{~S}$ ribosomal RNA genes. Mar Ecol Prog Ser 33:33-44

Submitted: June 15, 2001; Accepted: October 29, 2001 Proofs received from author(s): January 3, 2002 